\title{
Epigraphy in Tenth- and Eleventh-Century Armenia: Inscriptions as Bridges and Boundaries
}

\author{
Anne Elizabeth Redgate \\ University of Newcastle upon Tyne
}

\begin{abstract}
This article brings epigraphy, history, architecture, archaeology and liturgy together in an investigation of royal political ambitions and identity in tenthand eleventh-century Armenia, offering a new dimension to the usual study of inscriptions. It considers royal Armenian responses to monuments in the landscape, both ancient and recently constructed, and how the kings of two different dynasties proclaimed their greatness and their legitimacy as kings in stone, but in different ways.
\end{abstract}

Key words: Ałt'amar, Ani, Gagik Artsruni, identity, inscriptions, landscape.

\section{Introduction}

Epigraphy is a specialised discipline in its own right, but one that is of considerable interest to linguists and literature specialists as well as to medieval historians such as myself, because of the questions of what, and how, inscriptions communicate, and what their authors envisaged their audience(s) to be. The south-east and north-east of tenth- and eleventh-century historic Armenia (much larger than today's Republic (Hewsen 2001:13, 268) offer some interesting case studies. Those that this article is concerned with fall under two headings. There are inscriptions that the Armenians of this period inherited, from the ancient state of Urartu and from their own Christian ancestors. There are also inscriptions that tenth- and eleventh-century Armenians made, on the island of Ałt'amar in Lake Van, and in the city of Ani. The context of the Armenian ones is royal building programmes: the one that King Gagik Artsruni, 
whose kingship was based on Ałt'amar, undertook early in the tenth century, and those that the Bagratuni kings, based in Ani, undertook later in that century and in the eleventh century. These are, respectively, in today's southeast and north-east Turkey (Hewsen 2001:111, 113, 117). We have contemporary accounts of Gagik's building (Thomson 1985:18-19, 315-319, 352-361; T' ovmay 1887:252-256, 290-299), but only in the case of Holy Cross, his palace church on Ałt'amar, do we have material remains (Der Nersessian 1965; Mnatsakanian 2010; Davies 1991; Jones 2007). As for Ani, contemporary textual references to its buildings (its walls and churches) are less detailed than for Gagik's, but the material remains there are considerable (Marr 2001; Thierry and Donabédian 1987:481-489; Cowe 2001; Grigoryan 2015; Maranci 2018:5766). These monuments and their political contexts have been the object of significant scholarly work, but it has not embraced the particular concerns of this article.

The concerns of this article are twofold. One is the interrelationship, possibly rivalry, between the Artsruni and Bagratuni kingships, and its expression in architecture and in sculpture in stone. The other is the influence that historic monuments had upon the kings' buildings, that is, whether, and how, the kings were influenced by what they saw around them. These issues are themselves contexts for examining inscriptions both as bridges, and also as frontiers or barriers, regarding time, space and people. And there are other contexts too in which inscriptions were and are bridges. The Armenian ones, both the historic and the newly made ones, are on churches. A church is itself a liminal area, between this world and the next, and connecting past, present, and future. Inscriptions on a church functioned as prayers, and had a role in processions, strengthening historical memory.

The background to the needs of the northern and southern Armenian kingships to proclaim their legitimacy, to and within each other, is the following. There had long ago been a kingdom of Armenia, but it had been abolished in $428 \mathrm{AD}$, when its nobility requested the Persian shah to make what had been his client kingdom into a Persian province. Later, in the eighth and ninth centuries, the Arab-Byzantine frontier ran through Armenia 
(Hewsen 2001:104, 106). Most of Armenia was within an Arab province (Hewsen 2001:106), which had an Arab governor, the ostikan, though the Arabs entrusted supervision of the Armenians to one or other of the Armenian native princes, making him prince of princes. In the ninth century the Bagratunis had a stranglehold over this position, and in 884 , the nobility decided to make the then prince of princes, Ashot Bagratuni, king, informing the Caliph of this through the ostikan. What followed was recognition by the Caliph, some sort of investiture by the ostikan, coronation by the Catholicos (the head of the Armenian Church), and some recognition by the Byzantine Emperor (Maksoudian 1987:128, 129; Garsoïan 1997:147-148; Jones 2007:16-20). Sadly, Ashot's son and successor, King Smbat I (890/91-914), fell out with successive ostikans, and with some of his own nobles. War followed, and Smbat himself died a martyr's death, to be succeeded by his son, King Ashot II (914-928/29). But by 914 there was another kingship. In 908, the ostikan Yusuf had crowned Gagik Artsruni, who was prince of Vaspurakan, in southern Armenia, and, through his mother, Smbat's own nephew (Jones 2007:25-26). Gagik received Caliphal recognition, and his title was the same as Ashot I's and Smbat I's, namely king of the Armenians, which is often translated as 'king of Armenia'. After Gagik died, probably in 943, 'King of Vaspurakan' was used, for his son and later successors, in Vaspurakan. This change of title reflected a shift in the balance of power. Gagik had been the most powerful king in Armenia, and was recognised as such by Byzantium (Garsoïan 1997:158-162; Zuckerman 2014:847). But later, the Bagratuni kings of Ani were pre-eminent. They used the title king of kings, differentiating them from both the Artsruni kings and other kingships, which proliferated (Zuckerman 2014:844, 847-849; Greenwood 2011:52-53). King Ashot III (952/53-977) had granted the title 'king' to his brother Abas (963), who was based in Kars, and later there was another northern kingdom, based in Lori, and yet another in Siunik' in eastern Armenia (Garsoïan 1997:166; Hewsen 2001:115).

Thus, when King Gagik Artsruni began building his church of the Holy Cross in 915 (Der Nersessian 1965:5), shortly after King Smbat's martyrdom, he 
certainly needed to demonstrate his legitimacy as king, and he may also have wanted to proclaim his equality with former rulers.

\section{Historic Inscriptions in the Landscape}

What did King Gagik see, that might have challenged and inspired him in these endeavours? There were two kinds of inscriptions in the landscape: Urartian ones from Urartu's empire of the mid-ninth to mid-seventh centuries $\mathrm{BC}$, and Christian Armenian ones. Urartian inscriptions are famous as sources for Urartian history. The earliest are in Assyrian script and language, and a very few are in hieroglyphs. The rest are in Urartian, in Urartian cuneiform (Redgate 2016; Özdem 2003:121; Sagona and Zimansky 2009:338, 341). Most of the known Urartian inscriptions are on cliff faces, steles and buildings, and metal objects. Some $25 \%$ of them are reasonably substantial (Özdem 2003:121). Royal inscriptions, which are the majority, include commemorations of building works, of campaigns and conquests. But display inscriptions were much more than mere records, they were places where the Urartian kings manifested themselves, and were impressive, to illiterate, as well as to literate viewers. Most such inscriptions are associated with Van (Zimansky 1998:279) (which the Urartians called Tushpa), that is, from the Rock of Van and the old city beneath it, not today's city. Tushpa was Urartu's capital for all of its history except for a while at the beginning. Of course, what was visible to Urartians, and is now known by scholars through observation, reports, old photographs, and archaeological discoveries, would not all have been visible to tenth-century Armenians. The end of Urartu had itself featured a lot of destruction, and over the following centuries sites had suffered further destruction, or decayed, or been built over.

However, what is visible on the Rock of Van now, from below it, and on site, was probably visible in the tenth century. From below one can see what look like worked recesses or niches, and a post-Urartian inscription, legible only with binoculars or a zoom camera. This is by the Achaemenid Persian king Xerxes I (485-464 BC), in Babylonian, Old Persian and Median, probably meant to emulate and surpass Urartian ones, to state mastery. There are rock tombs 
within the cliff, including one of a king, that has a long inscription in Urartian cuneiform on the smoothed rock face around its door. There are rock-cut steps, a niche with a stele, further Urartian inscriptions, and remains of citadel walls (Sinclair 1987:179-184). Gagik Artsruni must have seen all these. Van was part of Artsruni territory, and he knew it well. According to the contemporary historian T'ovmay Artsruni, Gagik's father had built on the Rock of Van, and so did Gagik himself (Thomson 1985:315-316; T'ovmay 1887:252-253). An earlier Armenian historian had noted the ancient inscriptions on the rock at Van, which he ascribed to the legendary Assyrian queen Semiramis (Thomson 1978:101; Movsēs 1913:54).

Neither Armenian princes and kings nor their aristocracy stayed in one place all the time. They travelled, for war, for diplomatic visits, and around their domains. So Gagik will have seen Urartian works at sites that lie beyond Van. Of especial importance are Meher Kapısı (Sinclair 1987:188) and Anzaf (Sinclair 1987:261-262), which were nearby, and beyond them, Pagan (Sinclair 1987:263); and Edremit, with its canal (Sinclair 1987:219-220), which was on the Van-Ałt'amar coastal road. Çavuştepe (Sinclair 1987:208-212), and Eski Norgũh (Sinclair 1987:221), which are on the road from Van to Soradir, are also relevant, since Soradir was another place that Gagik almost certainly knew. The plan of Soradir's church may have been the model for Att'amar's, and the church itself may have been the site of the Artsrunis' family mausoleum (Cuneo 1968; Breccia-Fratadocchi 1971; Jones 2007:102), until the later tenth century. (After that, the Artsrunis used the monastery of Varag, near Van, instead.)

The most important of these sites is Meher Kapıs1, six miles from Van/Tushpa. Its Urartian cuneiform inscription was probably unintelligible in the tenth century, though now some scholars perceive it as perhaps a record of Urartu's constitution, since it names and ranks deities, and particular deities were associated with particular places and peoples. It prescribes what animals were to be sacrificed, annually, in the month of the sun god, at that very site, to 79 deities (Belli 1999:29-33). Visually however, some of its meaning is still clear, and must have been in the tenth century. In the rock face, which is above today's road, and was described in the late nineteenth century as about fifty feet 
above ground level (Lynch 1965:112), there is an inscribed panel, which is 14.5 feet high. It is recessed inside two matching rectangular frames, so it looks like a door. Indeed, its inscription refers to it as a gate. And its name, Meher Kapis1, means 'The Gate of Meher'. It is very imposing from below, and must surely have always aroused interest and wonder. Providentially, there is evidence that it did. In Armenian tradition the site is the Raven's Rock at Van in which, according to the Armenian poem, the Epic of Sasun, Little Mher, one of its heroes, who is cursed by his father, is imprisoned alive until the end of time (though two of the 24 versions site the cave elsewhere) (Russell 2014). The Epic goes back to the tenth century, and King Gagik Artsruni himself seems to lie behind one of its characters, Gagik, King of Armenia (Kouymjian 2013:21, 22; Der Melkonian-Minassian 2013:80-81). It is therefore likely that the site was visible, and perceived as a gate, in his time. In the story, the Rock opens every year at Ascension and Transfiguration, though different versions of the Epic have once, twice or even five times a year (Russell 2014:43). There is another legend that the Rock opened every year on the festival of St John, the seventh day of Easter (Sinclair 1987:188).

The other inscriptions with which King Gagik would have been familiar were those on Armenian churches, much shorter than that of Meher Kapisı. The oldest known Armenian monumental inscription is fifth-century. It is now lost, so is known only through reports, photographs, and a cast that was made in 1912 and that is in Erevan. It was on a lintel on the west door of the church at Tekor (Digor), in north-east Armenia. The two lowest of its five lines record Sahak Kamsarakan's building a martyrium of Saint Sergius. It was to intercede for himself and for his family (line 3). The upper three lines say that the place itself had been founded by five other people: Tayron, a priest of the monastery; Manon, a hazarapet, Uran, a Roman; Yohan, the Catholicos; and Yohan the bishop of the Arsharunik' (Durand, Rapti and Giovannoni 2007:61-62).

The one inscription that I myself have studied is at the seventh-century church at Ptłni, also in north-east Armenia, and near Erevan, the capital of today's Republic. In the seventh century Ptłni was part of the domain of the Amatuni family. The decoration of an arch above one of this church's windows 
includes a hunt scene, each with one hunter, on either side, and figures above. Scholars have interpreted the two hunters as being either two dead forebears of the founder of the church, or as two current patrons of it. The inscription is three words, over the scene which is on the viewer's left, and names its hunter, Manuēl, têr (that is lord) of the Amatunis. Over the hunter who is to the viewer's right, there is a bird in the equivalent space (Maranci 2015:201-254). I myself have suggested that the two hunters should not in fact be interpreted as either both dead or both living at the time of the construction. I have argued that the bird has the same function as the inscription, which is as an identifier, and that the two identifiers mean that one hunter is dead and one is alive (Redgate 2012:14-16). Manuel is the living donor, the other, a heroic forebear. This forebear is Pargev Amatuni. As Christina Maranci has demonstrated, Pargev's portrait reproduces a historical account of how he was killed in, probably, the $380 \mathrm{~s}$, by the Persians, after failing in an attempt to rescue his king, Khosrov, who had been deposed. He was 'blown up like a wine skin' (Maranci 2015:214-217; Thomson 1978:314-315; Movsēs 1913:321).

The decoration of this window at Ptłni has the same liturgical dimension that Tim Greenwood has suggested for Armenia's seventh-century foundation inscriptions (Greenwood 2004:35). As Maranci has noted, from liturgical sources collated by Daniel Findikyan, a church's consecration ritual involved processing around the exterior (Maranci 2015:76-77; Findikyan 1998). And it is likely that there were one or more annual commemorations at a church after its consecration. At Ptłni, these will have been of the church's foundation, or of Pargev's death, or of both, and possibly, later, of Manuell's death. The hunt scenes will have been viewed from processions, and requests will have been made, in prayers, to Pargev and to the other saints depicted above the arch, for intercession, for both living and dead members of the community, including the donor, Manuēl (Redgate 2012:16-17). Furthermore, processions would not have been limited to anniversaries. There will also have been penitential processions in which litanic prayer was used. These were a long-standing feature of the Eastern Church (Lapidge 1991:8, 16, 24, 45, 48, 58, 59). 


\section{King Gagik Artsruni: Buildings, Inscriptions, \\ Self-Publicity and Intercession}

Since Ptłni is far away both spatially and temporally from early-tenthcentury Aft'amar, it might be suspected of being a long way from it conceptually too. But actually it is not. By King Gagik's time the Amatunis had moved into the Artsruni orbit. They had provided loyal support to his grandfather and father as well as to himself, and they were in a sense one of the foundations of his power (Redgate 2007:11; Thomson 1985:176, 213, 289-291, 301, 321-322; T'ovmay 1887:109, 146-147, 226-227, 238, 258-259). And some features of the sculpture at Ałt' amar are foreshadowed at Ptłni, as Maranci has noted in her study of Ptłni (Maranci 2015:246-248), and as I have noted in mine (Redgate 2012:22-23). Gagik could have drawn on the Amatunis' cultural resources as well as their military ones.

Although Holy Cross is all that remains of his palace and urban buildings there, it is clear that Gagik's Ałt' amar was as impressive as Urartian towns and citadels had been in their day. Like them, they claimed and dominated the landscape, and, judging by the textual accounts, Gagik's works at Van, and at Ostan (Vostan) (modern Gevaş) on the mainland, opposite Ałt' amar, did too (Pogossian 2017:185-193, 202-203, 208-210).

But Gagik did not emulate Urartian kings with regard to inscriptions. He did not use inscriptions to state his greatness, and to proclaim the legitimacy of his kingship and its superiority to that of his Bagratuni rivals. Instead he used figural sculpture. Sadly, the belfry that was added to the middle of the south façade of Holy Cross in, probably, the nineteenth century (Der Nersessian 1965:10; Davies 1991:15) dominates it now, distorting its tenth-century impact. But the placing at either end of this façade of two biblical models of kingship, the king of Nineveh, and David, emphasised Gagik's descent from, and emulation of, both of them (Jolivet 1981; Der Nersessian 1965:Plate 15; Mnatsakanian 2010:106-107, 128; Thomson 1985:82, 313; T'ovmay 1887:20, 251). His own small portrait, seated, within the vine frieze, above a portrait of Adam, on the east façade (Jones 2007:57-58), implies that his status was like that of Adam and like that of Christ, as indeed do other features of the church, as 
several scholars have argued (Jolivet-Lévy 1997:240-241; Jones 1994:108-113; Jones 2007:72-80; Dorfmann-Lazarev 2016a:333-336, 338; Dorfmann-Lazarev 2016b:496-498). His full length, over life-size, standing, portrait with Christ, who is shorter, on the west façade, also implies a Christ-like status. This is in part because in Byzantine and other artistic traditions stature was one method of indicating status. Scholars have disagreed as to whether the greater height of Gagik was deliberate or a mistake, but to my knowledge none have interpreted his height as signifying Christ-like status. In addition, as Lynn Jones has shown, it proclaims that Gagik will attain salvation. The presence of two seraphim in the scene suggests that it is set outside time, in Heaven, portraying the success of the penitence which, according to a contemporary Artsruni writer, the portrait depicts (Jones 2007:82; Thomson 1985:360-361; T'ovmay 1887:298). As I have argued elsewhere, his face in this portrait seems designed to stress his trustworthiness, in contrast to the Bagratunis' oath-breaking (Redgate 2014:336-340). These claims not only answer the Bagratunis' claim to be descended from David, by pointing out that Gagik (through his mother) was too. They also state that, as a king, Gagik was more Davidic than the Bagratunis were, and more favoured by God.

In his self-publicity, Gagik seems to have eschewed inscriptions. The contemporary historians do not mention any. There are Armenian inscriptions on Holy Cross, but only one of them is unanimously regarded by scholars as original. This is the biblical quotation on the book, which looks closed, that Christ holds, on the west façade, 'I am the light of the world' (from John 8:12). The book has been perceived as an open book (Davies 1991:5). The inscription indicates a conceptual similarity between Gagik's palace church and the great church of Hagia Sophia in Constantinople, capital of the Byzantine Empire. 'I am the light of the world' is a motif which was dominant at Hagia Sophia in the late ninth and early tenth century. It is most obvious today in a mosaic in the narthex, which, probably, was made during Emperor Leo VI's reign (886-912) and depicts him, though opinions have differed. (Oikonomides 1976; Gavrilović 1979; Cormack 1994). Here Christ holds a book which is clearly open and is inscribed (in Greek) 'peace unto you I am the light of the world'. It is, however, 
possible that Gagik had a second inscription made, a long one on the west façade that was hidden by the gawit (forechurch) that was added in 1763 (Der Nersessian 1965:10), though the inscription itself could have been a later addition. This inscription too has a Byzantine resonance, implying an equality with Byzantium, given that Leo VI was known as 'the wise', and as a 'new Solomon'. For according to a text which was put together in the late eighteenth, and finished in the early nineteenth century, Gagik took six years to finish his church (915-921). Sirarpie Der Nersessian, citing Ervand Lalayan, suggested that this information may have come from this long inscription (Der Nersessian 1965:5). The claim of six years implicitly invites comparison with the Old Testament King Solomon, and possibly even the conclusion that Gagik surpassed him. According to the Bible (I Kings 6:38), Solomon took seven years to build the Temple of Jerusalem.

There are indeed other inscriptions at Ałt'amar, that, like the Pttni inscription, identify individuals. These individuals are the majority of the 61 persons, at least 41 of whom are biblical, who feature in Ałt' amar's main band of sculptural reliefs, which is about six and a half feet high. Thirty-eight of the sixty-one are identified (Davies 1991:17, 21). But these inscriptions seem likely to be later additions, though just how much later, is unclear. Although Lalayan and Der Nersessian thought that they were original (Mnatsakanian 2010:54), J.A. Orbeli and Stepan Mnatsakanian thought they were later. Mnatsakanian noted that the forms of the letters of 'Prophet David' on the north façade are seventeenth-century (Mnatsakanian 2010:60-61). On the east façade, below the portrait that is almost certainly of Gagik (Jones 2007:57), there is one of another man, flanked by animals (Jones 2007:78-80). An inscription identifies it, as Adam naming the animals. Mnatsakanian agreed with Orbeli that this was an attempt to Christianise the band of animal reliefs (Mnatsakanian 2010:53-55). In general he thought that there was a great deal of secular, even pagan, imagery, in the church's decoration, and that the inscriptions were an attempt to Christianise this, at a time when it was no longer deemed respectable. J.G. Davies by contrast thought that the inscriptions are indeed later than the sculptures, but that they do record the sculptures' original meanings. His view 
was that they were added to preserve their meaning at a time when it was in the process of being forgotten (Davies 1991:17-18).

As noted above, one function of inscriptions was as prayers. A viewer, viewing them, would activate them. Yet it was probably felt that inscriptions did not actually depend on a viewer to activate them, to be effective, at a particular moment, but that they worked independently, and all the time. Certainly in Byzantium it was thought that inscribed words spoke on their own, with a silent 'voice' (Papalexandrou 2001). It is also likely that the many images of saints at Ałt'amar were thought to do the same as inscriptions, just as pictures, and buildings themselves, were in Byzantium. The Aft'amar images were pictorial inscriptions, just as, as I have argued, the figures over the window at Ptłni were (Redgate 2012:16-17), constituting a pictorial litany, acting as intercessors for King Gagik. In addition, according to the Artsruni Continuator, on Ałt'amar's west façade, Gagik himself was 'depicted as if begging forgiveness for his sins' (Thomson 1985:360-361; T'ovmay 1887:298).

\section{Bagratuni Ani: the Decoration of the Cathedral, \\ Horomos, and Inscriptions}

Thus figural sculpture alone at Ałt'amar did for Gagik what the later inscriptions at Ani cathedral did for its Bagratuni royal patrons. This building was begun in 989, by King Smbat II (977-989/90), and finished in 1001, by the wife of his successor, King Gagik I Bagratuni (989/90-1017/20). It was near Ani's main square, at the junction of two main roads, and would have been visible both from the main gate on the north of the city and from the large bridge that spanned the River Akhurean to its south (Donabédian 2001:43). Thus, though it did not dominate its city from above, as Gagik Artsruni's Holy Cross on Ałt' amar did and as Urartian temples had, it would, like them, have been a major feature in the landscape, impressing approaching travellers, especially those who came from the south.

Ani cathedral's dome and drum have fallen, but most of its façades remain. They are very different from Ałt'amar's. First, there are few sculpted figural decorations, and these are relatively unobtrusive. The decoration of the south 
façade includes small reliefs of eagles above the central arch (Sinclair 1987:372373). There were two lions flanking the porch (Rapti 2015:188). There were some bands of ornament (Rapti 2015:188; Grigoryan 2015:30, 32, 34, 36-38). The main decorative element is the blind arcade (a series of sculpted arches) resting on sculpted narrow columns, which was a feature of the architectural school of Ani (Kazaryan 2017:532). In contrast to Ałt'amar's, these façades' surfaces are restrained. A third contrast is that epigraphy was used at Ani cathedral as a decorative element in itself. The inscription that commemorates its completion was, and is, at eye level, framed by arches (Rapti 2015:188). It must have drawn the eye, as is clear from old illustrations (Brosset 1861:PlateVIII). This is analogous to inscriptions on churches in neighbouring Georgia at the same time, which, Antony Eastmond has suggested, were designed to be seen as much as read. They had a decorative function and they were visual prayers, imprinting an icon of prayer on the mind of viewers, looking as if they were readable though actually being less readable than they look (Eastmond 2015:76-82, 87, 89). The Ani inscription may also have been intended to provide an historical record, as indeed both it, and later, inscriptions at Ani became.

Inscriptions were likewise used by the Bagratunis as a decorative device at Horomos, about 9.3 miles north-east of Ani, where a monastic complex was begun c. 931-936, probably with royal patronage from the start (Vardanyan 2015). Armen Kazaryan has pointed out, regarding the gawitjamatun of St John's, which was built for King Yovhannēs-Smbat Bagratuni (1017-1040/41), in 1038, that the ornamental power of lapidary inscriptions is especially impressive on its walls (Kazaryan 2015:142). Yovhannēs-Smbat's nine-line inscription is on the jamatun's west façade, above the door (Karapetyan and Mahé 2015:417-418). It may have been King Ashot III who built the small chapel that is near Horomos's oldest surviving church (St Minas). Ashot may also have built the tomb-like structure that was to the chapel's south-west, though it is also possible that this was built just after his death in 977 (Kazaryan 2015:62-63). It may even have been his own tomb, for an inscription naming King Ashot was discernible on it in the nineteenth century (Karapetyan and 
Mahé 2015:406). This inscription does not however seem to be entirely reliable. Armen Manuk-Khaloyan has established that it was regularly effaced and rewritten in the nineteenth century (Manuk-Khaloyan 2013:164). It is nevertheless on inscriptions that the case for Horomos as the Bagratunis' royal mausoleum, an identification that has been repeatedly made in secondary literature, rests. One on the east wall of the chapel of St George states that Gagik (Bagratuni) had founded it as a martyrium (Karapetyan and Mahé 2015:399-400). Yovhannēs-Smbat's inscription there (which names him as Smbat not Yovhannēs-Smbat), on the west wall, refers to the monastery of Horomos as the royal resting place, recording that he had given it a village in 1036 (Karapetyan and Mahé 2015:400-402).

\section{Conclusion}

In conclusion, it seems, first, that in the early tenth century, King Gagik Artsruni emulated and equalled the Urartians in his building, but without imitating their use of inscriptions. Instead, he used figural sculpture to communicate his greatness. Second, the figural sculpture, with its messages, of his church on Ałt' amar was neither emulated nor challenged by the Bagratunis. Although the Bagratunis did not eschew figural sculpture entirely, their messages about their kingship lay elsewhere, in architectural form and in epigraphy. I intend to discuss the issues of the royal building programmes and the particular buildings that are discussed in this article, in much greater detail in a forthcoming book.

\section{Notes:}

1. I dedicate this article to the memory of Jane Langhorne Rowlandson (25 December 1953-20 November 2018), dear friend, and distinguished papyrologist and historian of Roman Egypt, who would have enjoyed this topic.

2. A version of this article was read at the British Epigraphy Society Spring Meeting, whose programme was "Epigraphy and Frontiers", held in 
Newcastle upon Tyne, UK, 18 May 2019. I thank my colleague Dr Simon Corcoran for inviting me to speak at the Meeting.

\section{References:}

1. (1985) Artsruni Thomas: History of the House of the Artsrunik': Translation and Commentary. Detroit: Wayne State University Press.

2. Artsruni T'ovmay (1887) Patmut 'iwn Tann Artsruneats'. / Ed. by K.N. Patkanean. St Petersburg. Reprinted Tiflis 1917.

3. Belli, O. (1999) The Anzaf Fortresses and the Gods of Urartu. / Tr. by G.D. Summers and A. Üzel. Galatasary, Istanbul: Arkeoloji ve Sanat Yayinlari.

4. Breccia-Fratadocchi, T. (1971) La Chiesa de S. Ejmiacin a Soradir. Rome: de Luca.

5. Brosset, M.F. $(1860,1861)$ Les Ruines d'Ani Capitale de l'Arménie sous les rois bagratides, aux Xe et Xies. Histoire et Description 2 volumes. St. Petersburg: Commissionnaires de l'Académie Impériale des Sciences.

6. Cormack, R. (1994) The Emperor at St. Sophia: Viewer and Viewed. // Byzance et les images. / Ed. by A. Guillou. Paris: La documentation Française.

7. Cowe, S.P. (ed.) (2001) Ani: World Architectural Heritage of a Medieval Armenian Capital. Leuven and Sterling, VA: Peeters.

8. Cuneo, P. (1968) L'église de Sainte-Etchmiadzine à Soradir dans le Vaspurakan. // Revue des Études Arméniennes. New series, 5. Paris: Association de la Revue des Études Arméniennes.

9. Cuneo, P. (1984) Ani (Documents of Armenian Architecture 12). Milan: Edizioni Ares.

10. Davies, J.G. (1991) Medieval Armenian Art and Architecture: The Church of the Holy Cross, Aght 'amar. London: Pindar Press.

11. Der Melkonian-Minassian, C. (2013) The Historical and Geographical Setting of the Armenian Epic. // David of Sassoun: Critical Studies of the Armenian Epic. / Ed. by D. Kouymjian and B. Der Mugrdechian. Fresno: California State University. 
12. Der Nersessian, S. (1965) Aght'amar: Church of the Holy Cross. Cambridge, MA: Harvard University Press.

13. Donabédian, P. (2001) The Architect Trdat. // Ani: World Architectural Heritage of a Medieval Armenian Capital. / Ed. by S.P. Cowe. Leuven and Sterling, VA: Peeters.

14. Dorfmann-Lazarev, I. (2016a) Gagik Arcruni (908-943/44), un roi théologien. Le Christ selon sa "Lettre concernant la foi" et Adam dans le programme iconographique de l'église de la Sainte-Croix à Ałt'amar. // Journal of Eastern Christian Studies. 68 (3-4). Leuven: Peeters.

15. Dorfmann-Lazarev, I. (2016b) Kingship and Hospitality in the Iconography

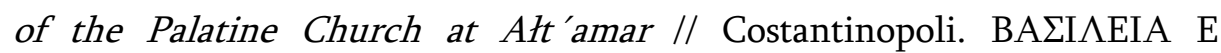
IEP $\Omega \Upsilon \Upsilon N H$. Studi in Memoria di Gilbert Dagron (monograph issue of the Rivista di Storia e Letteratura Religiosa). / Ed. by C. Alzati et al. 52 no. 3. Florence: Leo S. Olschki.

16. Durand, J., Rapti, R., and Giovannoni, D. (eds.). (2007) Armenia Sacra: Mémoire chrétienne des Arméniens (IVe-XVIIIe siècle). Paris: Musée du Louvre.

17. Eastmond, A. (2015) Textual Icons: Viewing Inscriptions in Medieval Georgia. // Viewing Inscriptions in the Late Antique and Medieval World. / Ed. by A. Eastmond. New York: CUP.

18. Findikyan, M.D. (1998) The Armenian Ritual of the Dedication of a Church: A Textual and Comparative Analysis of Three Early Sources. // Orientalia Christiana Periodica. 64. Rome: Pont. Institutum Orientalium Studiorum.

19. Garsoïan, N.G. (1997) The Independent Kingdoms of Medieval Armenia. // The Armenian People From Ancient To Modern Times. Volume I The Dynastic Periods: From Antiquity to the Fourteenth Century. / Ed. by R.G. Hovannisian. New York: St Martin's Press.

20. Gavrilović, Z.A. (1979) The Humiliation of Leo VI the Wise (the Mosaic of the Narthex at Saint Sophia, Istanbul). // Cahiers Archéologiques. 28. Paris: Picard. 
21. Greenwood, T. (2004) A Corpus of Early Armenian Inscriptions. // Dumbarton Oaks Papers. 58. Cambridge, MA: Harvard University Press.

22. (2011) The Emergence of the Bagratuni Kingdoms of Kars and Ani. // Armenian Kars and Ani. / Ed. by R.G. Hovannisian. Costa Mesa, CA: Mazda Publishers.

23. Grigoryan, A. (2015) Ani: The Millennial Capital of Armenia. (Armenian and English) Yerevan: History Museum of Armenia.

24. Hewsen, R.H. (2001) Armenia: A Historical Atlas. Chicago and London: University of Chicago Press.

25. Jolivet, C. (1981) L'idéologie princière dans les sculptures d'Aghthamar. // The Second International Symposium on Armenian Art, Yerevan, September 12-18, 1978. / Ed. by R.V. Zarian and B.N. Arakelian. Erevan: Armenian Academy of Sciences.

26. Jolivet-Lévy, C. (1997) Présence et figures du souverain à Sainte-Sophie de Constantinople et à l'église du la Sainte-Croix d'Aghtamar. // Byzantine Court Culture from 829 to 1204 . / Ed. by H. Maguire. Washington, DC: Dumbarton Oaks Research Library and Collection.

27. Jones, L. (1994) The Church of the Holy Cross and the Iconography of Kingship. // Gesta. 33. Fort Tryon Park, NY: International Center of Medieval Art.

28. Jones, L. (2007) Between Islam and Byzantium: Aght'amar and the Visual Construction of Medieval Armenian Rulership. Aldershot and Burlington, VT: Ashgate.

29. Karapetyan, S. and Mahé, J.-P. (2015) The Horomos Inscriptions. // Horomos Monastery: Art and History. / Ed. by E. Vardanyan. Paris: ACHCByz.

30. Kazaryan, A. (2015) The Architecture of Horomos Monastery. // Horomos Monastery: Art and History. / Ed. by E. Vardanyan. Paris: ACHCByz.

31. Kazaryan, A. (2017) The "Classical" Trend of the Armenian Architectural School of Ani: The Greco-Roman Model and the Conversion of Medieval Art. // A Handbook to Classical Reception in Eastern and Central Europe. / 
Ed. by Z. Martirosova Torlone, D. LaCourse Munteanu, and D. Dutsch. Chichester, West Sussex: John Wiley \& Sons.

32. Khorenats'i Movsēs. (1913) Patmut 'iwn Hayots '. / Ed. by M. Abełean and S. Yarut 'iwnean. Tiflis.

33. Kouymjian, D. (2013) 'Sasounts' i Davit': Synopsis of the Official Version of the Armenian Epic'. // David of Sassoun: Critical Studies of the Armenian Epic. Ed. by D. Kouymjian and B. Der Mugrdechian. Fresno: California State University.

34. Lapidge, M. (1991) Anglo-Saxon Litanies of the Saints. London: Boydell Press.

35. Lynch, H.F.B. (1965) Armenia: Travels and Studies Volume II The Turkish Provinces. (Reprinted) Beirut: Khayats.

36. Maksoudian, K.H. (1987) Yovhannēs Drasxanakertc 'i, History of Armenia: Translation and Commentary. Atlanta, GA: Scholars Press.

37. Manuk-Khaloyan, A. (2013) In the Cemetery of Their Ancestors: The Royal Burial Tombs of the Bagratuni Kings of Greater Armenia (8901073/79). // Revue des Études Arméniennes. New series, 35. Paris: Association de la Revue des Études Arméniennes.

38. Maranci, C. (2015) Vigilant Powers: Three Churches of Early Medieval Armenia. Turnhout: Brepols.

39. Maranci, C. (2018) The Art of Armenia: An Introduction. New York: OUP.

40. Marr, N.Y. (2001) Ani. Rêve d'Arménie. / Tr. by A. Tcharkhtchian. Paris: Anagramme Editions.

41. Mnatsakanian, S. (2010) Aghtamar. / Tr. by K.H. Maksoudian. / Ed. by A. Sarafian and O. Köker, in Aghtamar. A Jewel of Medieval Armenian Architecture/Ahtamar. Ortaçağ Ermeni Mimarllğinin Mücevheri. (English and Turkish). London and Istanbul: Gomidas Institute and Birzamanlar Yayincilik.

42. Oikonomides, N. (1976) Leo VI and the Narthex Mosaic of Saint Sophia. Dumbarton Oaks Papers. 30. Cambridge, MA: Harvard University Press.

43. Özdem, F. (ed.). (2003) Urartu: Savaş ve Estetik = Urartu: War and Aesthetics. Istanbul: Yap Kredi. 
44. Papalexandrou, A. (2001) Text in Context: Eloquent monuments and the Byzantine Beholder. // Word and Image: A Journal of Verbal/Visual Enquiry. 17. London: Taylor \& Francis.

45. Pogossian, Z. (2017) Locating Religion, Controlling Territory: Conquest and Legitimation in Late Ninth-Century Vaspurakan and its Inter religious Context. // Locating Religions: Contact, Diversity and Translocality. / Ed. by R.F. Glei and N. Jaspert. Leiden and Boston: Brill.

46. Rapti, I. (2015) Displaying the Word: Words as Visual Signs in the Armenian Architectural Decoration of the Monastery of Noravank' (Fourteenth Century). // Viewing Inscriptions in the Late Antique and Medieval World. / Ed. by A. Eastmond. New York: CUP.

47. Redgate, A.E. (2007) Morale, Cohesion and Power in the First Centuries of Amatuni Hamshen. // The Hemshin: History, Society and Identity in the Highlands of Northeast Turkey. / Ed. by H.H. Simonian. Abingdon and New York, NY: Routledge.

48. (2012) The Amatuni Hunting Scenes at the Seventh-Century Church of Ptmi: Patron and 'Propaganda'. // Journal of the Society for Armenian Studies. 21. Fresno, CA: Society for Armenian Studies.

49. (2014) Faces from the Past: Aghtamar, the Anglo-Saxon Alfred Jewel, and the Sasanian Chosroes Dish - Ideas and Influences in Portraiture. // Banber Matenadarani. (Proceedings of the $13^{\text {th }}$ General Conference of AIEA). / Ed. by H. Tamrazyan. 21. Yerevan: Nairi. Available at: <http://www. matenadaran.am/ftp/data/Banber-21.pdf> [Accessed June 2017].

50. (2016) Urartu, Kingdom of. // The Encyclopedia of Empire. / Ed. by J.M. MacKenzie and N.R. Dalziel. Chichester, UK and Hoboken, NJ: John Wiley \& Sons.

51. Russell, J.R. (2014) The Epic of Sasun: Armenian Apocalypse. // The Armenian Apocalyptic Tradition: A Comparative Perspective. Essays Presented in Honor of Professor Robert W. Thomson on the Occasion of his Eightieth Birthday. / Ed. by K.B. Bardakjian and S. La Porta. Leiden and Boston MA: Brill. 
52. Sagona, A. and Zimansky, P. (2009) Ancient Turkey. London and New York: Routledge.

53. Sinclair, T.A. (1987) Eastern Turkey: An Architectural and Archaeological Survey, Volume I. London: Pindar Press.

54. Thierry, J.M. and Donabédian, P. (1987) Armenian Art. New York: H.N. Abrams.

55. Thomson, R.W. (1978) Moses Khorenats'i, History of the Armenians: Translation and Commentary on the Literary Sources. Cambridge, MA and London: Harvard University Press.

56. Vardanyan, E. (ed.) (2015) Horomos Monastery: Art and History. Paris: ACHCByz.

57. Zimansky, P.E. (1998) Ancient Ararat: A Handbook of Urartian Studies. Delmar, NY: Caravan Books.

58. Zuckerman, C. (2014) Catholicos Anania of Mokk' on himself and on Armenia's rulers. // Mélanges Jean-Pierre Mahé. / Ed. by A. Mardirossian, A. Ouzounian and C. Zuckerman. Paris: Association des Amis du Centre d'Histoire et Civilisation de Byzance.

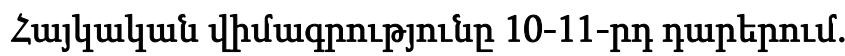

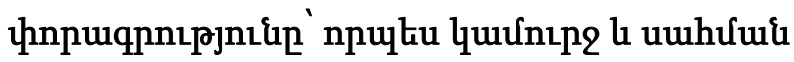

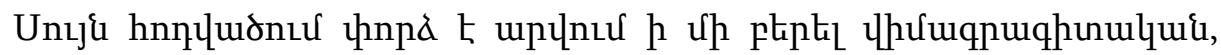





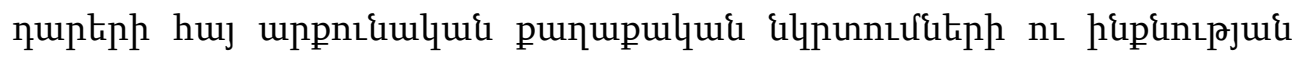

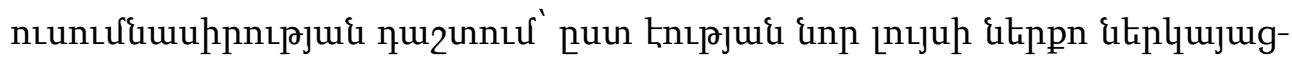

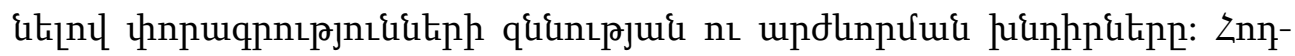

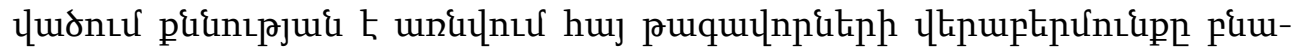

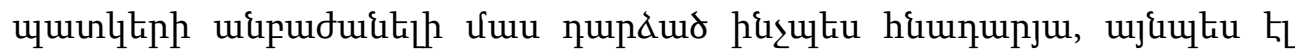

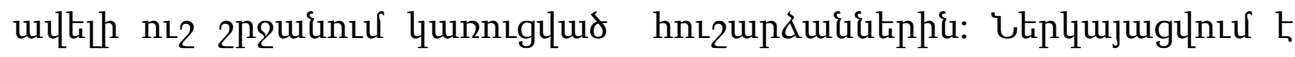

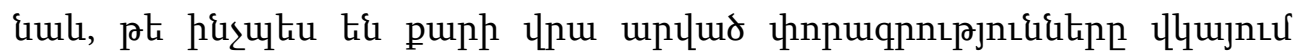




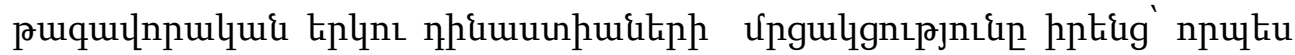

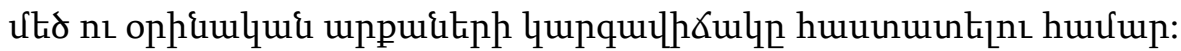

Received by Editorial Board 11.08.2019

Recommended for publication by Reviewers 25.10.2019

Accepted for Print 01.11.2019 